\title{
The Formation of the Pentateuch
}

\author{
Bridging the Academic Cultures of Europe, Israel, and North America \\ Ed. by Jan C. Gertz, Bernard M. Levinson, Dalit Rom-Shiloni, and Konrad Schmid
}

[Die Entstehung des Pentateuch. Ein Brückenschlag zwischen den akademischen Kulturen Europas, Israels und Nordamerikas.]

The Formation of the Pentateuch Edited by JAN C. GERTZ, BERNARD M. LEVINSO DALIT ROM-SHILONI, and KONRAD SCHMID

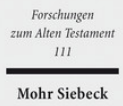

2016. XI, 1204 Seiten. FAT 111

ISBN 978-3-16-153884-1 DOI 10.1628/978-3-16-153884-1 eBook PDF $309,00 €$ ISBN 978-3-16-153883-4 Leinen $309,00 €$
Veröffentlicht auf Englisch.

Der Pentateuch ist einer der bekanntesten und wirkungsmächtigsten Texte der Weltliteratur. Trotz mehr als 200 Jahren kritischer Erforschung sind seine historischen Ursprünge und selbst die Umrisse seiner Literaturgeschichte in der wissenschaftlichen Diskussion stark umstritten. Man rechnet mit Quellen, Fortschreibungen und Redaktionen, doch die in Israel, Europa und Nordamerika vertretenen Sichtweisen divergieren stark voneinander. Dieser Band dokumentiert die Hauptrichtungen der gegenwärtigen Forschung und versucht, methodische und inhaltliche Wege aufzuzeigen, um zu einer grundlegenden Klärung von Voraussetzungen und Arbeitsweisen der internationalen Pentateuchforschung zu gelangen.

Inhaltsübersicht

Jan Christian Gertz/Bernard M. Levinson/Dalit Rom-Shiloni/Konrad Schmid: Convergence and Divergence in Pentateuchal Theory

1. Empirical Perspectives on the Composition of the Pentateuch

Jan Christian Gertz: Introduction - Christopher Rollston: Intellectual Infrastructure and the Writing of the Pentateuch: Empirical Models from Iron Age Inscriptions - David P. Wright: The Covenant Code Appendix (Exod 23:20-33), Neo-Assyrian Sources, and Implications for Pentateuchal Study - David M. Carr: Data to Inform Ongoing Debates about the Formation of the Pentateuch: From Documented Cases of Transmission History to Survey of Rabbinic Exegesis - Molly M. Zahn: InnerBiblical Exegesis: The View from beyond the Bible - Armin Lange: From Many to One: Some Thoughts on the Textual Standardization of the Torah

2. Can the Pentateuch Be Read in its Present Form? Narrative Continuity in the Pentateuch in Comparative Perspective Jeffrey Stackert: Introduction - Jean Louis Ska: What Do We Mean by Plot and by Narrative Continuity? - Yairah Amit: Travel Narratives and the Message of Genesis - Joe/ S. Baden: Why is the Pentateuch Unreadable? or, Why Are We Doing This Anyway? - Jeffrey Stackert: Pentateuchal Coherence and the Science of Reading - Jean-Pierre Sonnet: Does the Pentateuch Tell of Its Redactional Genesis? The Characters of Yhwh and Moses as Agents of Fortschreibung in the Pentateuch's Narrated World

3. How to Date Biblical Texts?

Shimon Gesundheit: The Strengths and Weaknesses of Linguistic Dating - Erhard Blum: The Linguistic Dating of Biblical Texts: An Approach with Methodical Limitations - Jan Joosten: Diachronic Linguistics and the Date of the Pentateuch - William Schniedewind: Linguistic Dating, Writing Systems, and the Pentateuchal Sources - Thomas Römer: How to Date Pentateuchal Texts: Some Case Studies - Noam Mizrahi: Historical Linguistics as a Chronological Control in Pentateuchal Research: The Linguistic Watershed of the Mid-Sixth Century BCE - Jakob Wöhrle: There's no Master Key! The Literary Character of the Priestly Stratum and the Formation of the Pentateuch - Frank H. Polak: Oral Platform and Language Usage in the Abraham Narrative - Frank H. Polak: Story Telling and Redaction: Varieties of Language Usage in the Exodus Narrative

4. The Significance of Second Temple Literature and the Dead Sea Scrolls for the Formation of the Pentateuch Bernard M. Levinson: Introduction - Sidnie White Crawford: What Constitutes a Scriptural Text? The History of Scholarship on Qumran Manuscript 4Q158 - Molly M. Zahn: Scribal Revision and the Composition of the Pentateuch: Methodological Questions Raised by 4Q158 Fragments 1-2 - Reinhard G. Kratz: Reworked Pentateuch and Pentateuchal Theory - Richard J. Bautch: »Holy Seed«: Ezra's Rhetoric and the Formation of the Pentateuch - Sara Japhet: What May Be Learned from EzraNehemiah about the Composition of the Pentateuch?

5. Evidence for Redactional Activity in the Pentateuch

Konrad Schmid: Introduction - Jean Louis Ska: Some Empirical Evidence in Favor of Redaction Criticism - Christoph Levin: The Pentateuch: A Compilation by Redactors - Konrad Schmid: Post-Priestly Additions in the Pentateuch: A Survey of Scholarship

6. The Integration of Pre-Existing Literary Material in the Pentateuch and the Impact Upon its Final Shape Joel S. Baden: Introduction - Rainer Albertz: Noncontinuous Literary Sources Taken up in the Book of Exodus - Itamar Kislev: The Story of the Gadites and the Reubenites (Numbers 32): A Case Study for an Approach to a Pentateuchal Text - Karin Finsterbusch: Integrating the Song of Moses into Deuteronomy and Reshaping the Narrative: Different Solutions in MT Deut 31:1-32:47 and (the Hebrew Vorlage of) LXX Deut 31:1-32:47 - David P. Wright: Source Dependence and the Development of the Pentateuch: The Case of Leviticus 24

7. Historical Geography of the Pentateuch and Archaeological Perspectives

Jan Christian Gertz: Introduction - David Ben-Gad HaCohen: Biblical Criticism from a Geographer's Perspective: "Transjordan« as a Test Case - Israel Finkelstein/Thomas Römer: Early North Israelite »Memories« on Moab - Thomas B. Dozeman: The Historical Geography of the Pentateuch and Archaeological Perspectives - Jan Christian Gertz: Hezekiah, 
Moses, and the Nehushtan: Some Remarks on a Case Study for a Correlation of the History of Religion in the Monarchical Period with the History of the Formation of the Hebrew Bible - Angela Roskop Erisman: For the Border of the Ammonites Was ... Where? Historical Geography and Biblical Interpretation in Numbers 21

\section{Do the Pentateuchal Sources Extend into the Former Prophets?}

Konrad Schmid: Introduction - Baruch J. Schwartz: The Pentateuchal Sources and the Former Prophets: A Documentarian's Perspective - Cynthia Edenburg: Joshua 1-5 within Hexateuch, Enneateuch and Deuteronomistic History Models - Thomas Römer: The Problem of the Hexateuch

\section{Rethinking the Relationship Between the Law and the Prophets}

Dalit Rom-Shiloni: Introduction - Konrad Schmid: The Prophets after the Law or the Law after the Prophets? Terminological, Biblical, and Historical Perspectives - Marvin A. Sweeney: Hosea's Reading of Pentateuchal Narratives: A Window for a Foundational E Stratum - Reinhard Achenbach: The Sermon on the Sabbath in Jer 17:19-27 and the Torah - Georg Fischer: ותפשי התורה לא ידעוני (Jer 2:8): The Relationship of the Book of Jeremiah to the Torah - Dalit Rom-Shiloni: Compositional Harmonization: Priestly and Deuteronomic References in Jeremiah_An Earlier Stage of a Recognized Interpretive Technique John Kessler: Patterns of »Descriptive Curse Formulae« in the Hebrew Bible, with Special Attention to Leviticus 26 and Amos 4:6-12 - MarkJ. Boda: Reading Zechariah 9-14 with the Law and the Prophets: Sibling Rivalry and Prophetic Crisis - Jakob Wöhrle: Jacob, Moses, and Levi: Pentateuchal Figures in the Book of the Twelve - Christophe Nihan: Branching Mosaic and Prophetic Discourses on the Exile: Leviticus 26 and Ezekiel - Ariel Kopilovitz: What Kind of Priestly Writings did Ezekiel Know? The Case of Leviticus 26 - Michael A. Lyons: How Have We Changed? Older and Newer Arguments about the Relationship of Ezekiel and the Holiness Code - Tova Ganzel/Risa Levitt Kohn: Ezekiel's Use of Leviticus 26

10. Reading for Unity, Reading for Multiplicity: Theological Implications of the Study of the Pentateuch's Composition Benjamin Sommer: Introduction - Benjamin Sommer: Book or Anthology? The Pentateuch as Jewish Scripture - Markus Witte: Methodological Reflections on a Theology of the Pentateuch - Jean-Pierre Sonnet: The Dynamic of Closure in the Pentateuch - James W. Watts: Narratives, Lists, Rhetoric, Ritual, and the Pentateuch as a Scripture

Jan C. Gertz is Professor of Hebrew Bible/Old Testament at the Ruprecht-Karls-Universität Heidelberg. https://orcid.org/0000-0003-0328-9463

Bernard M. Levinson is Professor of Jewish Studies and Hebrew Bible and of Law at the University of Minnesota in Minneapolis.

Dalit Rom-Shiloni is Associate Professor of Hebrew Bible at the Department of Biblical Studies, Tel Aviv University.

Konrad Schmid Born 1965; professor of Old Testament and Ancient Judaism at the Faculty of Theology at the University of Zürich, Switzerland.

https://orcid.org/0000-0002-8968-2604

Jetzt bestellen:

https://mohrsiebeck.com/buch/the-formation-of-the-pentateuch-9783161538841?no cache=1

order@mohrsiebeck.com

Telefon: +49 (0)7071-923-17

Telefax: +49 (0)7071-51104 